\section{JURNAL ABDIMAS

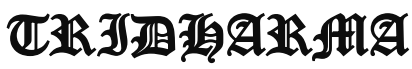 \\ AHA}

\title{
MEMBANGUN AFTER SALES YANG BAIK UNTUK MENINGKATKAN KUALITAS PELAYANAN PADA BENGKEL NAWILIS CABANG PARUNG BOGOR
}

\author{
Agrasadya, Ading Sunarto, Putri Nilam Kencana, Muger Apriansyah, Laila Irawati \\ Dosen Fakultas Ekonomi dan Bisnis \\ Universitas Pamulang

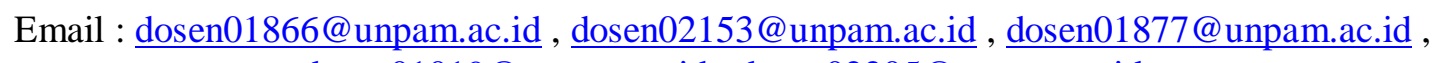 \\ dosen01019@unpam.ac.id, dosen02205@unpam.ac.id
}

\begin{abstract}
ABSTRAK
Tujuan dari kegiatan pengabdian kepada masyarakat di Bengkel Nawilis Cabang Parung Bogor ini untuk memberikan pengetahuan dan wawasan tentang bagaimana melaksanakan pelatihan terhadap karyawan dan bagaimana meningkatkan pemberian reward dan punishment bagi karyawan serta meningkatkan motivasi karyawan dalam belerja.

Metode pelaksanaan pengabdian ini dilakukan dalam beberapa kegiatan yaitu tahap survei yaitu sosialisasi dilakukan dengan menyusun berbagai hal yang akan disampaikan pada saat kegiatan pengabdian yang akan dilakukan yang meliputi: penyusunan materi yang akan diberikan, penyusunan jadwal pemberian materi, pembagian tugas tim pengabdian dan survei ke lokasi pengabdian. Tahap sosialisasi yaitu sebelum kegiatan pengabdian dilaksanakan terlebih dahulu dilakukan tahap sosialisasi yaitu melakukan silaturahmi dengan kepala sekolah, menyampaikan maksud dan tujuan pengabdian ini. Pada tahap ini juga dilakukan jalinan kerjasama dan menentukan jadwal kegiatan pengabdian. Tim pelaksana kegiatan pengabdian pada masyarakat adalah dosen Fakultas Ekonomi dan Bisnis jurusan manajemen sebanyak 5 orang. Tim pengabdian memberikan pelatihan dalam bentuk materi dan praktek dalam menghadapi permasalahan yang ada.

Hasil pengabdian masyarakat yang diperoleh adalah bertambahnya pengetahuan bagi Para Peserta (karyawan) di Bengkel Nawilis Cabang Parung Bogor agar mereka terlatih meningkatkan kualitas pelayanannya serta motivasinya semakin meningkat dalam upaya memperbaiki skill mereka. Ilmu yang diperoleh pada Pengabdian Masyarakat kali ini diharapkan mampu memberikan semangat baru bagi kita dalam menyampaikan materi dan motivasi serta berkontribusi bagi generasi muda, baik dilingkungan dunia usaha, kampus dan keluarga.
\end{abstract}

\section{Kata Kunci: Pelatihan, Pelayanan, After Sales}

\section{ABSTRACT}

The purpose of this community service activity at Bengkel Nawilis Parung Bogor Branch is to provide knowledge and insight on how to carry out training for employees and how to increase the provision of rewards and punishments for employees as well as increase employee motivation in work.

The method of implementing this service is carried out in several activities, namely the survey stage, namely socialization is carried out by compiling various things that will be conveyed during the service activities that will be carried out which include: preparation of material to be given, preparation of material delivery schedule, division of service team tasks and surveys to locations devotion. The socialization stage, which is before the service activities are carried out, the socialization stage is carried out, namely conducting a relationship with the principal, conveying the aims and objectives of this service. At this stage, cooperation is also carried out 


\section{JURNAL ABDIMAS

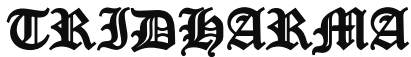 AHA}

P-ISSN 2615-6849, E-ISSN 2716-070X

Jurnal ABDIMAS Vol.3,No.1,Desember 2021,Hal(50-56)

@ Prodi Manajemen Fakultas Ekonomi Universitas Pamulang

Email: abdimasjurnal.unpam@ gmail.com Telp: (021) 741-2566

and determines the schedule of service activities. The implementing team for community service activities is 5 lecturers from the Faculty of Economics and Business majoring in management. The service team provides training in the form of material and practice in dealing with existing problems.

The results of community service obtained are increased knowledge for Participants (employees) at Bengkel Nawilis, Parung Bogor Branch so that they are trained to improve the quality of their services and increase their motivation in an effort to improve their skills. The knowledge gained in Community Service this time is expected to be able to provide new enthusiasm for us in conveying material and motivation as well as contributing to the younger generation, both in the business world, campus and family.

\section{Keywords: Training, Service, After Sales}

\section{PENDAHULUAN}

Seiring dengan semakin meningkatnya permintaan masyarakat terhadap produk dan jasa serta Perkembangan dunia bisnis yang semakin dinamis untuk memenuhi segala kebutuhannya dan Demi kelangsungan usaha di tengah persaingan bisnis yang sangat kompetitif, suatu perusahaan harus memberikan pelayanan yang baik terhadap kepuasan pelanggannya.

Nawilis adalah salah satu pionir bengkel mobil dan spesialis SpooringBalancing di Jakarta yang memahami kebutuhan pelanggan dan memberikan penyelesaian terbaik yang dilatarbelakangi oleh ketrampilan dan pengalaman di bidangnya selama lebih dari 50 tahun. Kami melayani semua merk mobil dan semua jaringan dari customer perorangan/pribadi sampai corporate. Nawilis melayani semua merk mobil dan semua jaringan dari customer perorangan/pribadi sampai corporate. Tujuan Nawilis adalah senantiasa menyajikan kualitas kerja yang prima dalam upayanya memenuhi kepuasan pelanggan dalam bentuk keamanan dan kenyamanan berkendara. Nawilis juga menyediakan onestop service untuk kebutuhan perawatan kendaraan, baik dalam barang maupun jasa. Barang-barang yang tersedia termasuk: Ban, Oli, Aki, Sparepart, Aksesoris dan Velg. Jasa-jasa yang tersedia antara lain: Spooring, Balancing, Tune-Up, Flushing AC, Engine Flush, Bubut piringan rem, Kuras minyak rem, Ganti Oli, Kuras minyak power steering dan transmisi.

Seluruh bengkel mobil NAWILIS telah didukung oleh perangkat peralatan computerized terkini dengan dukungan sumber daya manusia yang memiliki pengalaman dan dedikasi di bidangnya dalam memenuhi standar mutu yang ditetapkan. NAWILIS memiliki Standard Operasional yang disetarakan antara semua lokasi sehingga customer dengan mudah dapat berkunjung ke cabang terdekat. NAWILIS selalu memberikan training berkelanjutan agar tingkat kompetensi karyawannya berkembang.

Adanya persaingan bisnis yang ketat mampu memicu banyak pebisnis dalam melakukan berbagai macam cara untuk menghadapi persaingan tersebut, salah satu caranya adalah dengan menonjolkan after sales service. Lantas, kenapa after sales service lebih sering dijadikan pilihan daripada cara yang lain? Padahal secara makna yang terkandung di dalamnya, cara ini tidak langsung menjaga hubungan yang baik dengan penjual dan pembeli. Tapi secara fungsi, cara ini memiliki peranan yang baik dalam membentuk keberlangsungan hubungan bisnis. Iklim bisnis yang ketat memicu banyak penjual melakukan ragam cara guna menjawab tantangan persaingan, after sales service merupakan salah satunya. Di antara sekian cara yang digunakan, after sales service jadi pilihan. Mengapa? Secara makna, metode ini tidak langsung menjaga hubungan antara penjual dan pembeli. Namun, secara fungsi, metode ini juga berperan sebagai bentuk keberlangsungan hubungan bisnis.

Pada dasarnya, after sales service lebih mengacu pada berbagai upaya untuk memastikan pihak pembeli sudah merasa puas dengan layanan atau produk yang dijual 


\section{JURNAL ABDIMAS

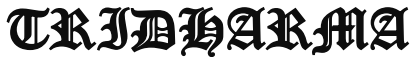 AHA}

P-ISSN 2615-6849, E-ISSN 2716-070X

Jurnal ABDIMAS Vol.3,No.1,Desember 2021,Hal(50-56)

@ Prodi Manajemen Fakultas Ekonomi Universitas Pamulang

Email: abdimasjurnal.unpam@ gmail.com Telp: (021) 741-2566 oleh perusahaan. Cara ini dilakukan agar pihak pembeli merasa puas dan secara tidak langsung akan rela memberikan rekomendasi produk atau layanan perusahaan pada kerabatnya. Walaupun memang tidak akan memengaruhi tingkat penjualan secara signifikan, tapi para penjual sudah seharusnya mampu memberikan rasa puas pada pembeli. Kenapa? Karena perasaan puas ini akan mampu menciptakan hubungan baik antara pihak penjual dan pihak pembeli.

Hubungan yang baik antara pihak penjual dan pihak pembeli tidak akan langsung membentuk terjadinya pembelian ulang atau hal serupa lainnya. Namun, kondisi tersebut akan membuat pembeli merekomendasikan produk atau jasa perusahaan pada kerabatnya secara sukarela. Secara teknis, terdapat beberapa hal yang harus dilakukan pada proses tersebut. Diantaranya adalah dengan meminta pendapat pada para pembeli terkait produk atau layanan yang sudah mereka dapatkan, hingga membantu para pelanggan jika mereka mengalami kesulitan dalam penggunaan barang.

After sales service mengacu pada berbagai proses yang memastikan pembeli puas dengan produk dan layanan yang dijual. Prinsip ini dilakukan agar pembeli merasa puas dan secara tidak langsung mau merekomendasikan produk atau layanan tersebut. Meski tidak mempengaruhi penjualan secara signifikan, penjual semestinya harus bisa menciptakan rasa puas kepada pembeli. Hal ini dikarenakan, perasaan tersebut akan menciptakan hubungan yang apik antara penjual dan pembeli. Menurut Management Study Guide, hubungan yang baik tidak serta merta berbentuk pembelian ulang atau sejenisnya. Namun juga, kondisi dimana pembeli akan merekomendasikan penjual terhadap orangorang terdekatnya. Secara teknis, ada beberapa hal yang wajib dilakukan dalam proses ini. Di antaranya, meminta pendapat pembeli saat menggunakan produk atau layanan, hingga membuat bantuan pengguna apabila mereka kesulitan.

Ada beberapa hal yang dampaknya amat besar bagi kemajuan bisnis penjual. Hal menguntungkan pertama yang bisa didapatkan dari after sales service adalah loyalitas konsumen. Mengapa harus loyalitas konsumen? Karena persaingan bisnis di zaman digital amat keras dan sulit untuk membuat konsumen loyal terhadap satu produk atau layanan. After sales service rupanya juga memiliki peran terhadap peningkatan penjualan. Hal ini bisa diukur lewat bagaimana proses tersebut mempengaruhi pembeli untuk melakukan strategi pemasaran berupa word of mouth dan mengisi review pembelian. Perbaikan di sini memiliki banyak makna. Bisa secara kualitas produk, strategi penjualan, dan sebagainya. Dengan melakukan after sales service, penjual bisa meminta pembeli melakukan review pembelian, yang tentu akan menampilkan kelebihan serta kekurangan produk atau jasa. Sehingga, hasilnya bisa menjadi landasan evaluasi untuk peningkatan kualitas produk dan layanan ke depannya.

\section{RUMUSAN MASALAH}

Dengan mempertimbangkan latar belakang yang telah dijelaskan diatas kami berinisiatif untuk membentuk pengabdian masyarakat bagi karyawan di Bengkel Nawilis Cabng Parung Bogor khususnya dalam program penyuluhan pelatihan dan pendidikan membangun After Sales yang baik untuk meningkatkan kualitas pelayanan. Dari identifikasi masalah tersebut, dapat dirumuskan masalah sebagai berikut:

1. Bagaimana melaksanakan pelatihan terhadap karyawan Bengkel Nawilis Cabang Parung Bogor?

2. Bagaimana meningkatkan pemberian Reward kepada karyawan dan proses pemberian Punishment yang baik bagi karyawan?

3. Bagaimana meningkatkan motivasi karyawan dalam bekerja?

\section{TUJUAN PELAKSANAAN}

1. Memberikan pengetahuan dan wawasan kepada peserta di Bengkel Nawilis Cabang Parung Bogor dalam bentuk pelatihan.

2. Memberikan pengetahuan kepada peserta di Bengkel Nawilis Cabang 


\section{JURNAL ABDIMAS

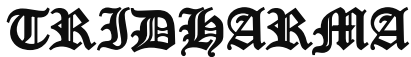

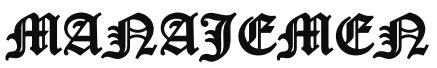

P-ISSN 2615-6849, E-ISSN 2716-070X

Jurnal ABDIMAS Vol.3,No.1,Desember 2021,Hal(50-56)

@ Prodi Manajemen Fakultas Ekonomi Universitas Pamulang

Email: abdimasjurnal.unpam@ gmail.com Telp: (021) 741-2566
Parung Bogor mengenai Reward dan Punishment.

3. Meningkatkan motivasi kerja karyawan di Bengkel Nawilis Cabang Parung Bogor.

\section{TINJAUAN PUSTAKA}

\section{Membangun After Sales yang baik}

After-sales service menurut Lele dan Karmarkar $(2002,40)$ yaitu "The service that expected from the product can be specified into three areas: reliability, service dependability, and maintance". After-sales service yaitu layanan yang diharapkan dari sebuah produk yang dapat dispesifikasi kan kedalam tiga bidang yaitu: reliabilitas, ketergantungan terhadap layanan dan perawatan.

Menurut Patton $\quad(2002,41)$ menyatakan bahwa after-sales service adalah "a product support that can keep the product work properly for along time". Suatu layanan pendukung produk yang bertujuan untuk membuat suatu produk dapat bekerja dengan wajar untuk jangka waktu yang lama. Menurut Hindle \& Thomas (2004,53) mendefinisikan after-sales service sebagai "a service that provided by the company to their costumers, after the customer purchasing their product". Suatu layanan yang disediakan oleh produsen kepada seorang konsumen, setelah konsumen tersebut melakukan pembelian pada produsen tersebut.

Menurut Mathe \& Saphiro $(2002,42)$ menyatakan bahwa "After-sales service is more than merely fixing what has gone wrong, which appears to be the primary function of many after sales service functions". After-sales service lebih sekedar memperbaiki sesuatu yang telah rusak yang muncul menjadi fungsi utama dari banyak fungsi-fungsi after-sales service yang ada.

Tjiptono menjelaskan bahwa after sales service adalah suatu layanan yang disediakan oleh pihak produsen kepada para konsumen pasca konsumen membeli atau menggunakan produk dari tersebut. Sementara Kotler dan Armstrong berpendapat bahwa after sales service adalah suatu layanan yang disediakan oleh pihak produsen untuk pihak konsumen pasca konsumen membeli produk dari perusahaan. Kemudian Hindle dan Thomas menjelaskan bahwa after sales service adalah suatu layanan yang disediakan oleh pihak produsen setelah pihak konsumen membeli produk ataupun menggunakan jasa dari pihak produsen. Jadi, berdasarkan para ahli tersebut, maka bisa kita tarik kesimpulan bahwa after sales service adalah suatu kegiatan yang dilakukan oleh pihak produsen setelah produk diserahkan kepada pihak konsumen atas pembeliannya selama konsumen memiliki ikatan ataupun layanan atau juga hubungan dalam suatu aktivitas.

Terdapat beberapa jenis kegiatan after sales service yang banyak dilakukan oleh pihak penjual, beberapa contohnya adalah sebagai berikut:

Pengemasan Barang, Pengiriman adalah hal yang paling banyak dilakukan dalam suatu kegiatan penjualan. Dalam hal ini, produsen harus mampu memberikan kesan yang baik pada proses pengirimannya. Salah satu caranya adalah mengubah kebiasaan dalam mengemas suatu barang. Suatu kemasan yang memiliki kualitas baik dan menarik memiliki suatu nilai yang besar jumlahnya. Para pengguna akan lebih terkesan dengan kemasan yang menarik dan akan membuat mereka lebih senang daripada suatu produk yang dikemas hanya dengan bungkus karton saja.

Kupon dan Voucher, adanya pembelian barang ataupun layanan yang baru tidak akan membuat pembeli langsung puas atau senang. Perasaan tersebut akan muncul secara normal karena nalurinya saja. Nah, untuk bisa mengatasi hal tersebut, perusahaan bisa memberikan kupon ataupun voucher. Strategi ini banyak digunakan pada pemesanan tiket pesawat online. Dalam setiap tahunnya, mereka biasanya memberikan suatu kupon ataupun voucher tertentu sebagai bentuk permintaan maaf atas adanya keterbatasan dalam kuantitas produk yang dijualnya.

\section{HASIL DAN PEMBAHASAN}

Kegiatan Pengabdian Masyarakat Universitas Pamulang yang dilakukan oleh dosen-dosen program studi Manajemen S1 Fakultas Ekonomi dan Bisnis telah berjalan 


\section{JURNAL ABDIMAS

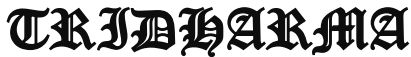 AHA}

P-ISSN 2615-6849, E-ISSN 2716-070X

Jurnal ABDIMAS Vol.3,No.1,Desember 2021,Hal(50-56)

@ Prodi Manajemen Fakultas Ekonomi Universitas Pamulang

Email: abdimasjurnal.unpam@ gmail.com Telp: (021) 741-2566 dengan lancar dan mendapat sambutan hangat dari tempat pelaksanaan kegiatan ini yaitu di Bengkel Nawilis Cabang Parung Bogor.

.Peserta diberikan pengetahuan tentang arti pentingnya after sales bahwa seperti yang sudah diketahui, persaingan dalam dunia bisnis sangatlah ketat, terlebih lagi konsumen saat ini akan lebih melakukan riset yang dalam sebelum melakukan pembelian. Harapannya adalah para penjual mampu memenuhi keperluan mereka dan juga memberikan respon masalah secara lebih efektif. Sehubungan dengan hal tersebut, bentuk pemenuhan kebutuhan dan juga korespondensi tidak hanya menjadi suatu hal penting yang ditawarkan di dalam after sales service.

Peserta juga diberikan motivasi agar memiliki kesadaran akan pentingnya kesadaran bertanggung jawab atas pekerjaannya masing-masing dalam menerapkan after sales service, karena dapat menciptakan loyalitas konsumen. Kenapa demikian? Karena persaingan bisnis di zaman digital seperti saat ini sangatlah keras dan juga sangat sulit untuk membuat konsumen menjadi lebih loyal pada suatu produk ataupun layanan.

Peserta PKM juga diberikan materi tentang After sales service yang mempunyai peranan yang penting pada peningkatan jumlah penjualan. Hal tersebut bisa dilihat dari bagaimana tersebut mampu memengaruhi pembeli untuk rela memberikan rekomendasi produk atau layanan perusahaan pada kerabat ataupun orang terdekatnya. Peserta PKM juga diberikan tips After Sales, yaitu :

1. Berterima Kasih atas Pembelian Melakukan terima kasih bisa menjadi awal bagi penjual setelah mereka sudah menyelesaikan transaksinya. Ucapan tersebut bisa dilakukan lewat berbagai macam media. Mulai dari email, kartu ucapan, atau lewat telepon.

\section{Hubungi Pelanggan}

Dalam kurun waktu satu ataupun dua minggu setelah pembelian selesai dilakukan, maka penjual setidaknya harus menghubungi pembeli untuk menanyakan layanan atau produk yang sudah didapatkannya.
Pertanyaan tersebut bisa berupa rasa kepuasaan, penerimaan layanan yang baik, atau menjawab pertanyaan dari penjual jika ada. Hal ini sebagai bentuk perhatian kepada pihak pelanggan atau pembeli saja, bukan demi penjualan yang lebih banyak.

3. Menjaga Komunikasi

Komunikasi harus tetap dilakukan secara berkala untuk menjaga hubungan yang harmonis. Umumnya, penjual dalam hal ini akan meminta saran terkait produk atau layanan, hingga peran customer support yang disediakan oleh perusahaan.

\section{Memberikan Garansi}

Garansi adalah salah satu faktor yang sangat penting dalam menjalankan layanan after sales service. Garansi bisa dilakukan untuk meyakinkan konsumen bahwa produk yang mereka terima bebas dari perusahaan, dalam keadaan baik, atau bebas dari ketidak telitian ataupun penggunaan material yang kurang baik.

5. Menyediakan Spare Part

Menyediakan suku cadang dalam upaya menjalankan layanan after sales service adalah hal yang penting, karena tanpa adanya suku cadang pada kerusakan produk, maka produk tersebut akan menjadi tidak bisa digunakan lagi oleh pembeli. Selain itu, hal ini juga sangat penting untuk mempertahankan loyalitas pelanggan.

6. Memberikan Pelayanan

Pemeliharaan dan Perbaikan

Poin akan penting bila suatu produk memiliki waktu konsumsi yang lama dan juga memerlukan perawatan yang teratur. Hal ini diperlukan agar produk bisa selalu berfungsi dengan baik dan juga melakukan perbaikan atas berbagai kerusakan yang terjadi pada produk selama penggunaannya.

7. Menyediakan Fasilitas dan

Perlengkapan

Salah satu sarana yang penting dalam kegiatan ini adalah fasilitas dan juga perlengkapan produk. Dengan adanya poin ini, maka akan mampu menentukan kelancaran pelayanan para petugas dalam hal menjalankan pemeliharaan dan juga perbaikan produk.

KESIMPULAN DAN SARAN Kesimpulan 


\section{JURNAL ABDIMAS

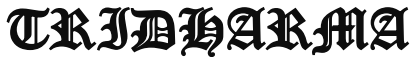

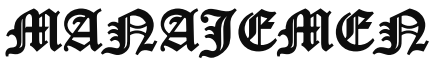

P-ISSN 2615-6849, E-ISSN 2716-070X

Jurnal ABDIMAS Vol.3,No.1,Desember 2021,Hal(50-56)

@Prodi Manajemen Fakultas Ekonomi Universitas Pamulang

Email: abdimasjurnal.unpam@ gmail.com Telp: (021) 741-2566
Berdasarkan hasil pelaksanaan kegiatan PKM yang telah dilakukan, dapat diambil kesimpulan bahwa peserta dapat meningkatkan pengetahuan sekaligus sebagai stimulasi agar peserta atau karyawan lebih aktif dalam bekerja dan semakin termotivasi.

Dalam keterbatasan waktu dan pengelolaan, tim menyadari waktu dan biaya untuk penyuluhan ini masih harus ditingkatkan untuk kegiatan PKM ini. Rencana tahapan berikutnya yang menurut tim gariskan diantaranya adalah sebagai berikut :

1. Penyuluhan terapan dan refleksi keterampilan yang sudah diberikan perlu untuk dimodifikasi dan ditingkatkan.

2. Produk-produk dari pelatihan yang sudah diberikan dan dibuatkan perlu untuk di dikembangkan kembali.

3. Perlu untuk adanya pelatihan marketing untuk belajar bagaimana menjalan after sales dengan baik.

4. Menjadi hal yang sangat mungkin dalam hal kewajiban dosen untuk melaksanakan tri dharma perguruan tinggi bagi dosen atas kewajibannya sebagai dosen untuk melakukan kegiatan PKM dan menjadikan Bengkel Nawilis Cabang Parung bogor sebagai tempat binaan dosen dalam mengembangkan

keilmuannya.

\section{Saran}

Mengadakan sosialisasi dan pelatihan serupa pada karyawan di bengkel lain yang serupa di Kecamatan yang lain, dengan materi yang serupa. Adanya kesinambungan program pasca kegiatan pengabdian ini sehingga para karyawan benar-benar dapat mengembangkan kemampuannya dalam berkreasi. Diadakannya kegiatan yang berkaitan dengan After Sales.

\section{DAFTAR PUSTAKA}

Bhumika, J.P. Bela, D. Dilip, D, Karmakar, P. Shah, M. dan Bhumi, S., 2015, Comparison and Correlation of Glucose Levels in Serum and Saliva of Both Diabetic and Non-Diabetic Patients,Journal of International Oral Health, No. 7-8, hal. 70-76

Hindle, Tim dan Thomas, Michael. (1994), Seri Intisari Manajemen Pemasaran, terjemahan, Damiano Q. Roosmin. Gramedia. Jakarta

Karmakar, M. \& R.R.Ray. (2011). Current Trends in Research and Application of Microbial Cellulases. Research Journal of Microbiology, 6, 41-53.

Panggarbesi, A. A., \& Sunarto, A. (2021). Kinerja Karyawan Berbasis Disiplin Dan Motivasi Pada PT. Pos Indonesia (Persero) Cabang Depok 2. Jurnal Ilmiah PERKUSI, 1(1), 12-17.

Pasaribu, V. L. D., Agrasadya, A., Shabrina, N., \& Krisnaldy, K. (2020). Menjadi Enterpreneur Muda Yang Memiliki Jiwa Leadership Untuk Menghadapi Masa Depan. Abdi Laksana: Jurnal Pengabdian Kepada Masyarakat, 1(1).

Pasaribu, V. L. D., Susanti, F., \& Hartuti, E. T. K. (2019). Memotivasi Siswa dan Siswi SMK Letris Indonesia di Dalam Menentukan Pilihan Untuk Melanjutkan Pendidikan Atau Bekerja Setelah Lulus Sekolah. Jurnal Pengabdian Dharma Laksana, 1(2), 161-172.

Pasaribu, V. L. D., Sulaiman, S., Sutiman, S., Thaharudin, T., \& Purnomo, B. Y. (2020). Pengenalan Letak Posyandu Terdekat Dikelurahan Pisangan Dengan Manajemen Pemasaran Revolusi 4.0 Untuk Meningkatkan Pengetahuan Masyarakat Letak Dan Fungsi Posyandu Terdekat Pada Kelurahan Pisangan. Dedikasi Pkm, 1(1), 105-110.

Pasaribu, V. L. D., Oktrima, B., Prabowo, B., Arianto, N., \& Haryoko, U. B. (2020). Progam Pendampingan Dan Penyelenggaraan Pendidikan Anak Pada Usia Dini Terhadap Prestasi 


\section{JURNAL ABDIMAS

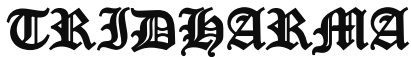 AlA:}

P-ISSN 2615-6849, E-ISSN 2716-070X

Jurnal ABDIMAS Vol.3,No.1,Desember 2021,Hal(50-56)

@Prodi Manajemen Fakultas Ekonomi Universitas Pamulang

Email: abdimasjurnal.unpam@gmail.com Telp: (021) 741-2566
Belajar Dilingkungan Rt $020 \mathrm{Rw}$ 009. Kel Giri Peni. Kec Wates. Yogyakarta. Jurnal Kreatif, 1(1), 71-75.

Pasaribu, V. L. D., Jannah, M., Fazar, M., Putra, S. P., Monalisa, M., \& Sofa, M. (2021). MENINGKATKAN PRODUKTIVITAS USAHA DIMASA PANDEMI PADA IBU PKK RT 004/003 KELURAHAN SAWAH BARU CIPUTAT, TANGERANG SELATAN. Abdi Laksana: Jurnal Pengabdian Kepada Masyarakat, 2(2), 295-301.

Pasaribu, V. L. D., Yuniati, H. L., Pranata, R., Sembayu, R., Purba, S. M., \& Nurbayani, T. T. A. (2021). MANAJEMEN KEUANGAN UNTUK MENGHADAPI DAN BERTAHAN DI ERA COVID 19. Jurnal Abdimas Tri Dharma Manajemen, 2(2), 12-18.

Pasaribu, V. L. D., Dwiyatni, A., Sabina, C., Ridwan, M., Gunawan, D. D., \& Noviani, B. C. (2021). EVALUASI PENERAPAN 3M DIMASA PANDEMIC COVID 19. Jurnal Abdimas Tri Dharma Manajemen, 2(2), 54-60.

Pasaribu, V. L. D., Syafei, A. N., Farhan, A., Aufaizah, A., Irani, C., \& Firtiayani, S. R. (2021). PENGARUH DISPLIN PROTOKOL KESEHATAN TERHADAP PENCEGAHAN PENULARAN VIRUS COVID-19. Jurnal Abdimas Tri Dharma Manajemen, 2(2), 91-98.

Pasaribu, V. L. D., Septiani, F., Rahayu, S., Lismiatun, L., Arief, M., Juanda, A., ... \& Rahim, R. (2021). Forecast Analysis of Gross Regional Domestic Product based on the Linear Regression Algorithm Technique.

Priadi, A., Pasaribu, V. L. D., Virby, S., Sairin, S., \& Wardani, W. G. (2020). Penguatan Ekonomi Kreatif Berbasis Sumber Daya Desa Dikelurahan Rempoa. Abdi Laksana: Jurnal Pengabdian
Kepada Masyarakat, 1(3), 356-35

Pasaribu, V. L. D., Priadi, A., Anismadiyah, V., Rahayu, S., \& Maduningtias, L. (2021). PENYULUHAN KREATIF DAN INOVATIF MENINGKATKAN MUTU PRODUKSI UMKM DI DESA BELEGA KABUPATEN GIANYAR. Pro Bono Jurnal Pengabdian Kepada Masyarakat, 1(02).

Pasaribu, V. L. D. (2021). PELATIHAN BERBASIS ONLINE DI ERA COVID-19. Jurnal Abdimas Tri Dharma Manajemen, 2(3), 26-32.

Pasaribu, V. L. D., \& Setyowati, R. (2021). ADAPTASI KEHIDUPAN NEW NORMAL PADA MASA PANDEMI COVID-19 DIYAYASAN PONDOK PESANTREN DAN PANTI ASUHAN NURUL IKHSAN KECAMATAN SETU, KOTA TANGERANG SELATAN. Jurnal Lokabmas Kreatif: Loyalitas Kreatifitas Abdi Masyarakat Kreatif, 2(2), 82-88.

Patton, Michael Quinn. 2002. Qualitative Research and Evaluation Methods. USA : Sage Publicatin Inc

Shapiro, E.Lawrence. (2003). Mengajarkan Emotional Intelligence Pada Anak. Jakarta: Gramedia Pustaka Utama.

Sunarto, A., \& Larasati, D. (2021). Pengaruh Pelatihan Dan Motivasi Kerja Terhadap Kinerja Karyawan PT. Asuransi Central Asia Jakarta Barat. Jurnal Ilmiah PERKUSI, 1(3), 402410.

Sunarto, A. (2021). PENGARUH PELATIHAN DAN KOMPENSASI TERHADAP KINERJA KARYAWAN CV MURNI RASA BOGOR. Jurnal Arastirma, 1(2), 326-335. 


\section{JURNAL ABDIMAS

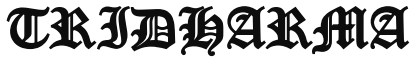 AIA}

P-ISSN 2615-6849, E-ISSN 2716-070X

Jurnal ABDIMAS Vol.3,No.1,Desember 2021,Hal(50-56)

@ Prodi Manajemen Fakultas Ekonomi Universitas Pamulang

Email: abdimasjurnal.unpam@gmail.com Telp: (021) 741-2566

Sunarto, A., \& Maulana, D. (2021). The Effect of Discipline and Physical Work Environment on Employee Productivity At PT. Liebra Permana Gunung Putri Bogor. Kontigensi: Jurnal Ilmiah Manajemen, 9(2), 318335.

Sunarto, A. (2020). KINERJA PEGAWAI

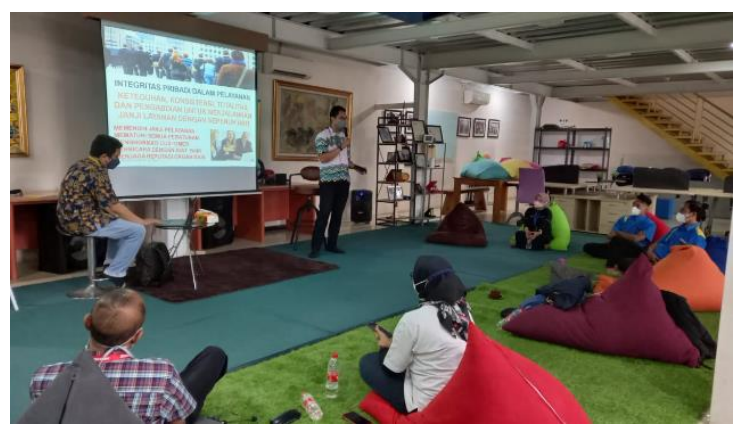
BERBASIS KEPEMIMPINAN DAN LINGKUNGAN KERJA PADA PT VICTORY CHINGLUH INDONESIA DIVISI QUALITY. KREATIF: Jurnal Ilmiah Prodi Manajemen Universitas Pamulang, 8(2), 92-101.

Sunarto, A. (2019). Analisis Kinerja Karyawan Pada PT. Bank Mandiri Cluster Cilegon I. SCIENTIFIC JOURNAL OF REFLECTION: Economic, Accounting, Management and Business, 2(3), 241-250.

Sunarto, A. (2020). Pengembangan Sumber Daya Manusia dengan Berbasis Inovasi Untuk Menghadapi Revolusi Industri 4.0. Jurnal Ilmiah MEA (Manajemen, Ekonomi, \& Akuntansi), 4(2), 397-407.

\section{DOKUMENTASI KEGIATAN}

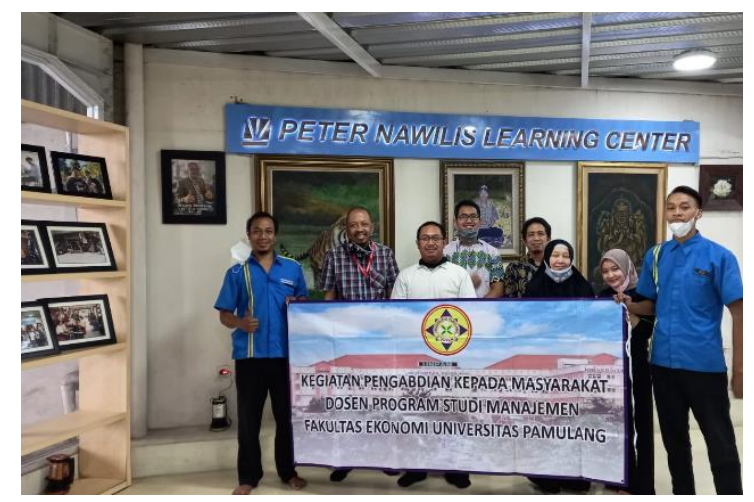

